\title{
Study on the Deterioration Mechanism of Concrete Pavement for the Deicer-scaling
}

\author{
Li Jun ${ }^{1,2}$, Gao Pei-Wei ${ }^{1, *}$ and Liu Hong-Wei ${ }^{1,3}$ \\ ${ }^{1}$ Department of Civil Engineering, Nanjing University of Aeronautic and Astronomics, Nanjing 210016,China \\ ${ }^{2}$ Civil Engineering College of Yancheng Institute of Technology, Yancheng 224051, China \\ ${ }^{3}$ Jiangsu Rongsheng Group Co., Ltd, Yangzhou 225100, P.R.China
}

\begin{abstract}
The mechanical properties of concrete pavement were studied under the various frost-salt conditions using Capillary Suction of De-icing Chemicals and Freeze-thaw Test Method (CDF method). The test results show that: with the increasing of freeze-thaw cycles, concrete surface damage has a tendency to accelerate. The concrete which is in a $5 \%$ concentration chloride snow-thawing agent solution has the greatest impact damage after 150 frost-salt cycles compared with soaking in other different densities $(3 \%, 20 \%)$. Mixing appropriate amount of silica fume and high-performance airentraining agent in concrete can effectively improve the resistance of frost-salt scaling. With the frost-salt cycles increase, the concrete strength and the relative dynamic elastic modulus continues to decrease.
\end{abstract}

Keywords: Concrete, frost-salt, chloride snow-thawing agent, mechanical properties.

\section{INTRODUCTION}

In cold region, freezing rain and snow will affect the road traffic especially in winter. So it is generally used to alleviate the traffic problems by seeding the chloride salt snowmelting agent on the road to remove snow and ice. But it will cause the spalling of concrete, corrosion of reinforcement, and the increasing damage by the freeze-thaw to the concrete pavement [1]. Damage cases caused by frost-salt are ever increasing. So many high grade concrete pavements and the urban overpass bridge decks are prematurely destroyed due to insufficient understanding of the damage of spreading snow-melting agent [2-9].

Frost-salt scaling has become the main cause of crack of concrete in cold areas. Although the research on the damage cases caused by deicer-scaling on the concrete pavement has already been done for many years [10-15], the theory measures of deicer-scaling with which to improve the frostsalt resistance of concrete pavement have not yet been unified. So there is an important academic significance and application value to carry out research on the influence of chloride salt snow-melting agent on concrete material properties.

*Address correspondence to this author at Department of Civil Engineering, Nanjing University of Aeronautic and Astronomics, Nanjing, China. Postcard: 210016; E-mail: gpw1963@ nuaa.edu.cn

\section{MATERIALS}

\subsection{Test Materials}

The raw materials in examination are as follows: Cement (P • II 52.5 portland cement); Fly ash (Class I fly ash); silica fume (specific surface area is $19-21 \mathrm{~m}^{2} / \mathrm{g}$, content of $\mathrm{SiO}_{2}$ is about 96.8\%); fine ore( limestone fines); sand (grit with the fineness modulus of 3.5); stone (basalt broken stones with the hardness of 7-7.5 grade).

\subsection{Admixture}

Water reducing agent (naphthalene superplasticizer); Airentraining agent (sodium dodecyl sulfate air-entraining agent); Magnesia expansive agent (self-control, magnesite with the specific surface area of about $310 \mathrm{~m}^{2} / \mathrm{kg}$ after crushing, grinding and light burning); Snow-melting agent (chloride salt snow-melting agent $\mathrm{A}$ with $80 \%$ content of sodium chloride and $20 \%$ content of calcium chloride, chloride salt snow-melting agent B with $70 \%$ content of sodium chloride and $30 \%$ content of calcium chloride and magnesium chloride).

\subsection{Design of concrete mix proportion}

C30 and C50 concrete are designed for the test purposes. Silica fume and admixtures are considered in the design of the C50 concrete. See Table 1 for details. 
Table 1. Concrete mix proportion and mechanical performance.

\begin{tabular}{|c|c|c|c|c|c|c|c|c|c|c|c|c|c|}
\hline \multirow{2}{*}{$\begin{array}{l}\text { Sample } \\
\text { number }\end{array}$} & \multirow{2}{*}{$\begin{array}{l}\text { Strength } \\
\text { grade }\end{array}$} & \multicolumn{6}{|c|}{ Dosage of mixture $/ \mathbf{k g} \cdot \mathbf{m}^{-3}$} & \multirow{2}{*}{$\begin{array}{c}\text { Water } \\
\text { reducing } \\
\text { agent } / \%\end{array}$} & \multirow{2}{*}{$\begin{array}{c}\text { Air- } \\
\text { entraining } \\
\text { agent } / \% \text { o }\end{array}$} & \multicolumn{2}{|c|}{$\begin{array}{c}\text { flexural } \\
\text { strength /MPa }\end{array}$} & \multicolumn{2}{|c|}{$\begin{array}{c}\text { compressive } \\
\text { strength } / \mathrm{MPa}\end{array}$} \\
\hline & & Cement & $\begin{array}{l}\text { Fly } \\
\text { ash }\end{array}$ & $\begin{array}{l}\text { silica } \\
\text { fume }\end{array}$ & Water & sand & stone & & & 7d & 28d & 7d & 28d \\
\hline $\mathrm{C} 30$ & $\mathrm{C} 30$ & 250 & 30 & 0 & 165 & 702 & 1248 & 0.9 & 3.8 & 6.59 & 8.17 & 27.8 & 37.3 \\
\hline C50 & $\mathrm{C} 50$ & 360 & 40 & 0 & 145 & 665 & 1182 & 1.6 & 3.8 & 8.69 & 9.91 & 45.1 & 66.1 \\
\hline C50S & $\mathrm{C} 50$ & 340 & 40 & 20 & 145 & 665 & 1182 & 1.6 & 3.8 & 9.56 & 10.49 & 55.1 & 77.0 \\
\hline C50A & C50 & 360 & 40 & 0 & 145 & 665 & 1182 & 1.6 & 1.0 & 7.42 & 8.32 & 33.4 & 60.3 \\
\hline
\end{tabular}

\section{EXPERIMENTAL}

\subsection{Effects of Frost-salt on Concrete Appearance Characteristics}

(1) Influence of frost-salt cycles times on the concrete appearance.

According to the "Test procedures of highway engineering cement and concrete" (JTGE 30-2005), the quick freezing method is used to study the influence of frostsalt cycles on the concrete appearance. In the concrete frost resistance test the Capillary Suction of Deicing Chemicals and Freeze-thaw Test Method (CDF method) is used according to International Union of Laboratories and Experts in Construction Materials, Systems and Structures (RILEM).

Through the statistics, the influence of frost-salt cycles on the concrete appearance is shown in Table $\mathbf{2}$.

(2) Influence of different concrete mix on the concrete appearance.

Four different mix concrete test blocks (C30, C50, C50S, C50A) are socked in the chloride salt snow-melting agent A solution with the concentrations of 5\% for 200 applications of frost-salt cycles. By statistical processing, under the same frost-salt conditions, the influence of different concrete mix influence on the concrete appearance is shown in Table $\mathbf{3}$.

\subsection{Effects of Frost-salt on the Concrete Mass Loss Rate}

The mass loss of concrete is due to the surface spalling of concrete test blocks under the frost-salt cycles. The mass loss of $\mathrm{C} 30$ and C50 concrete test blocks socked in 3\%, 5\%, and $20 \%$ of chloride salt snow-melting agent A and B solution, respectively, gradually increases with the increasing number of frost-salt cycles, as shown in Fig. (1).

With the increase of frost-salt cycle, concrete mass loss rate gradually increases, especially in the latter stages. This is because in the early stage of frost-salt cycle the mass loss of concrete is mainly caused by the cement pastes spalling and small amount of aggregate falling off, while in the latter stages of frost-salt cycle large amounts of aggregate and cement pastes are spalling off with the loss of cohesive strength, which can lead to serious disintegration of the concrete test block.

Table 2. Effects of frost-salt cycles on the concrete appearance.

\begin{tabular}{|c|c|c|c|c|c|c|}
\hline Strength grade & \multicolumn{6}{|c|}{$\mathbf{C 3 0}$} \\
\hline Type of agent & \multicolumn{3}{|c|}{ chloride salt snow-melting agent $A$} & \multicolumn{3}{|c|}{ chloride salt snow-melting agent $B$} \\
\hline Concentration & \multicolumn{3}{|c|}{$3 \%$} & $3 \%$ & $5 \%$ & $20 \%$ \\
\hline $\begin{array}{c}\text { Times of frost-salt } \\
\text { cycles }\end{array}$ & $\mathbf{0}$ & 75 & 200 & \multicolumn{3}{|c|}{150} \\
\hline Failure characteristics & $\begin{array}{l}\text { Conventional } \\
\text { form }\end{array}$ & $\begin{array}{c}\text { Surface paste fall off } \\
\text { seriously; } \\
\text { Part of aggregate } \\
\text { exposed; } \\
\text { Edge and angle } \\
\text { defected. }\end{array}$ & $\begin{array}{c}\text { Fracture crack } \\
\text { on surface; } \\
\text { Edge and angle } \\
\text { collapsing; } \\
\text { Basic loss of } \\
\text { mechanical } \\
\text { properties. }\end{array}$ & $\begin{array}{l}\text { Uneven surface; } \\
\text { All paste fall } \\
\text { off; } \\
\text { Almost } \\
\text { aggregate } \\
\text { exposed } \\
\text { completely. }\end{array}$ & $\begin{array}{l}\text { Surface paste all } \\
\quad \text { fall off; } \\
\text { Part of edge and } \\
\text { angle collapsing; } \\
\text { Serious damage }\end{array}$ & $\begin{array}{l}\text { Small of surface } \\
\text { paste fall off; } \\
\text { Overall structure } \\
\text { block remains }\end{array}$ \\
\hline Extent of damage & & Less serious & Serious & Less serious & Serious & General \\
\hline
\end{tabular}


Table 3. Effects of different concrete mix on the concrete appearance under the same frost-salt conditions.

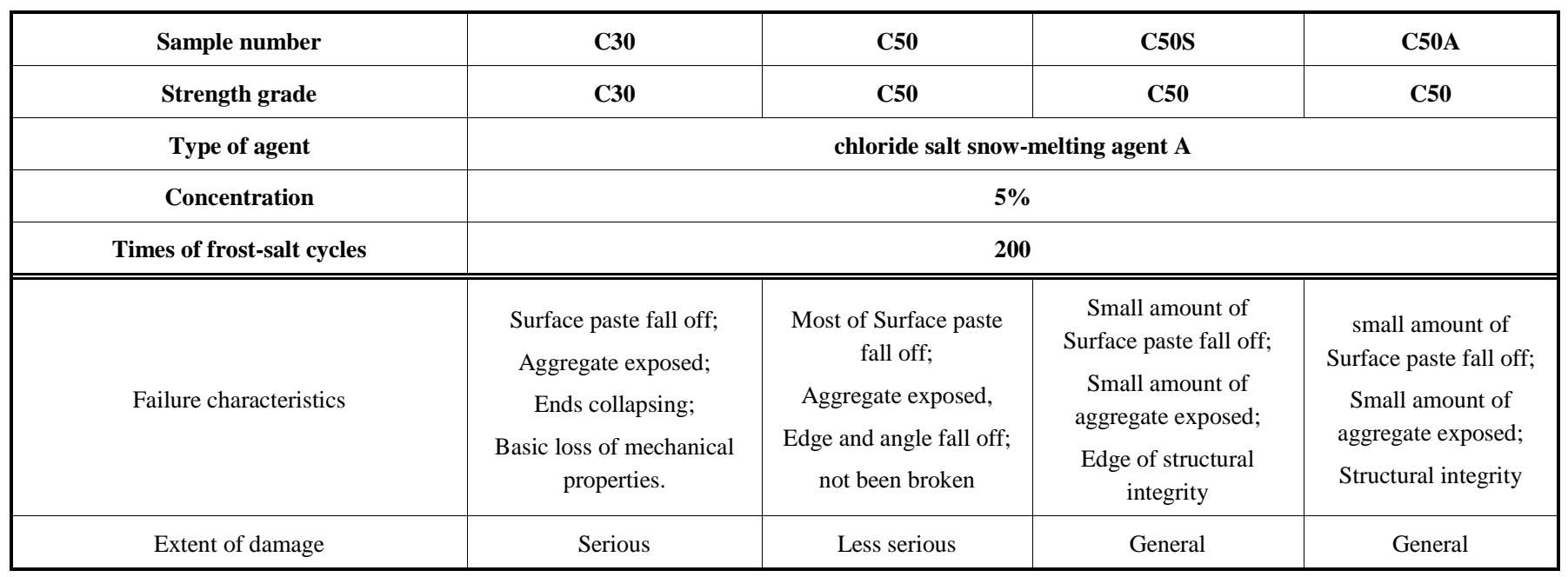

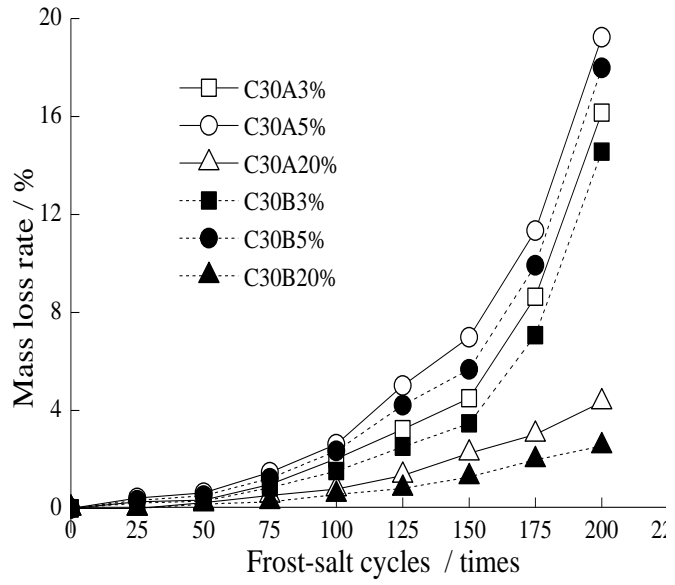

(a) $\mathrm{C} 30$

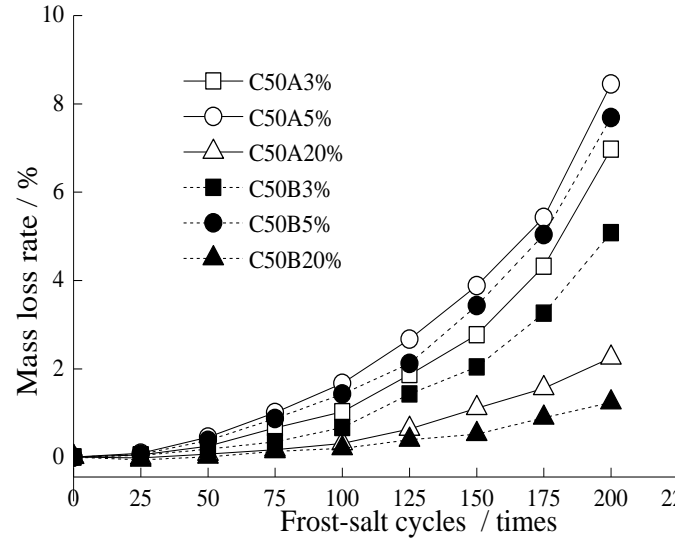

(b) $\mathrm{C} 50$

Fig. (1). Influence of different type and concentration of salt snow-melting agent solution on the mass loss rate of concrete.

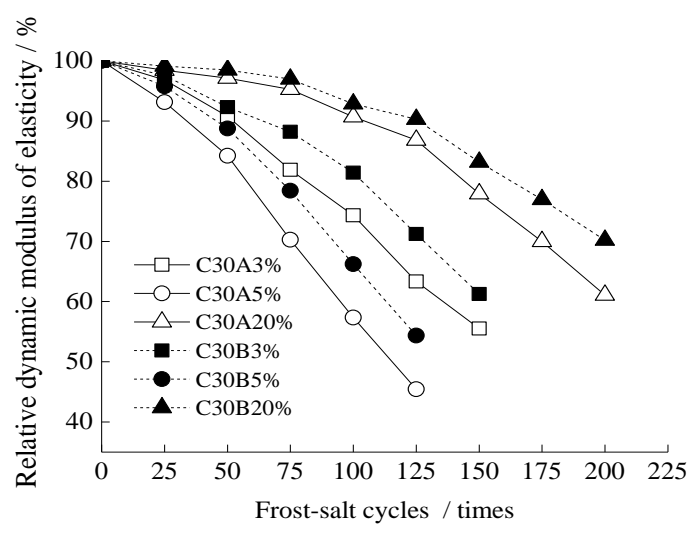

(a) $\mathrm{C} 30$

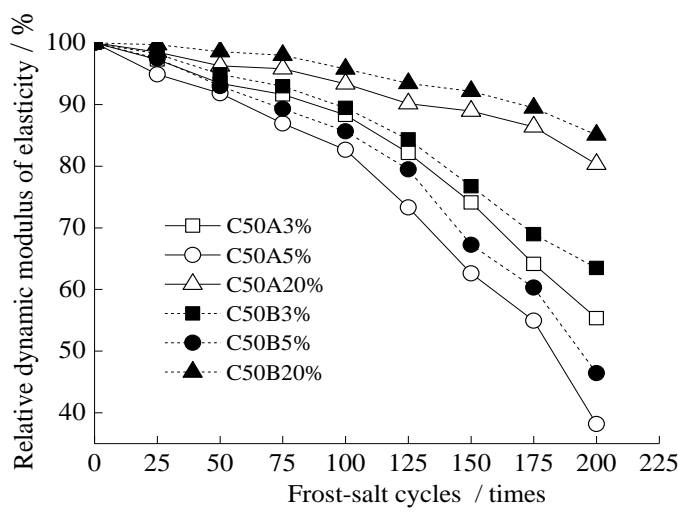

(b) C50

Fig. (2). Influence of different type and concentration of salt snow-melting agent solution on the relative dynamic elastic modulus of concrete.

\subsection{Effects of Frost-salt on the Relative Dynamic Elastic Modulus of Concrete}

Fig. (2) shows the relative dynamic elastic modulus of concrete $\mathrm{C} 30$ and $\mathrm{C} 50$, both of which are converted from the determination of concrete dynamic elastic modulus with the test block socking in 3\%, 5\%, and 20\% chloride salt snowmelting agent $\mathrm{A}$ and $\mathrm{B}$ solution, respectively, during the frost-salt cycles. It can be concluded that with the frost-salt cycles increasing, the relative dynamic elastic modulus will 
decline. Concrete strength has a positive correlation with the ability of the frost-salt damage.

\subsection{Effects of Frost-salt on the Concrete Strength}

(1) Influence of frost-salt cycles times on the concrete strength

Fig. (3) shows the changes of compressive and flexural strength of concrete C30 and C50 after different cycles (25, 75,150 and 200 cycles) of frost-salt application in 5\% chloride salt snow-melting agent A solution. With the increase of frost-salt cycles, the decrease of compressive and flexural strength of C30 concrete is greater than that of C50 concrete. After 200 cycles of frost-salt application, the compressive strength of C30 concrete is very small, while the flexural strength has been unable to be detected.

(2) Influence of concentrations of salt snow-melting agent solution on the concrete strength

Fig. (4) shows the change of concrete strength of C30 and C50 after150 cycles of frost-salt application in chloride

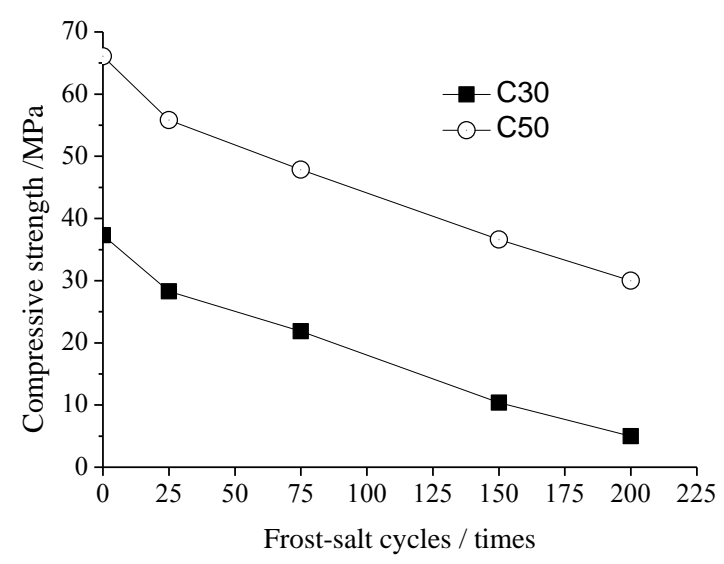

(a) compressive strength

Fig. (3). Influence of frost-salt cycles times on the concrete strength.

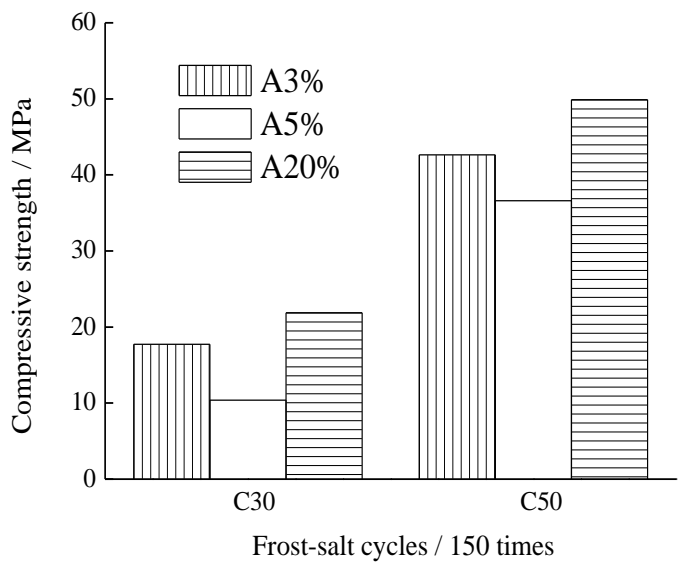

(a) compressive strength salt snow-melting agent A solution with different concentrations of $3 \%, 5 \%$ and $20 \%$. The largest decline of concrete strength is soaking it in 5\% solution, followed by $3 \%$, and the smallest decline is soaking in $20 \%$ solution.

\section{CONCLUSION}

(1) The damage of concrete appearance gradually intensifies with the increasing of frost-salt cycles and under the same conditions, the higher the grade of concrete strength, the smaller the frost-salt scaling. At the same strength grade, it can effectively improve the ability of frost-salt resistance of concrete by mixing appropriate amount of silica fume and efficient air-entraining agent.

(2) With the increase of frost-salt cycles, the mass loss of same strength grade concrete increases gradually, and in the latter stages the mass loss rate will rise sharply.

(3) After 150 cycles of frost-salt application, the biggest frost-salt damage of concrete is due to the soaking in

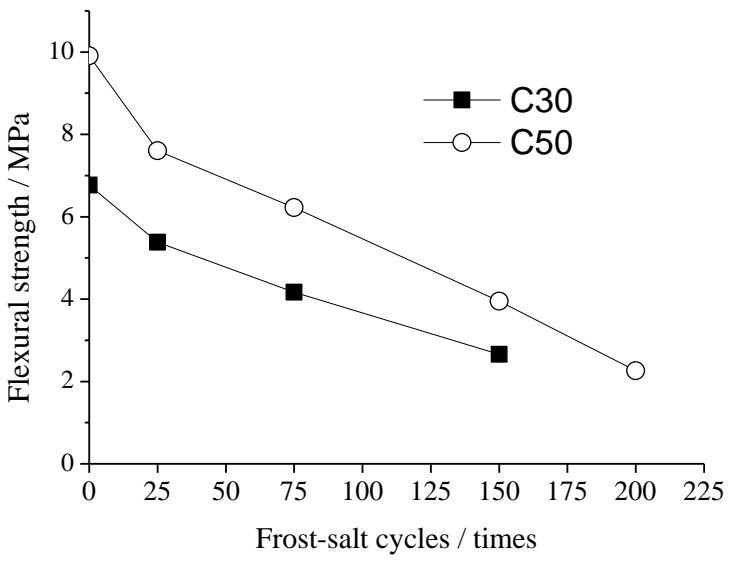

(b) flexural strength

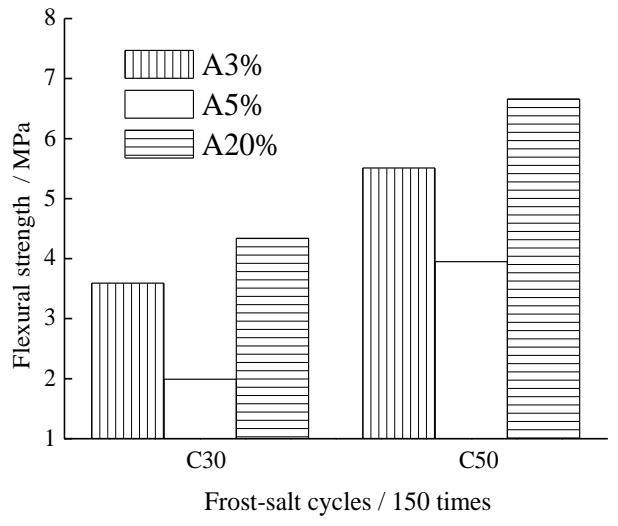

Fig. (4). Influence of concentration of salt snow-melting agent solution on the concrete strength. 
the $5 \%$ concentration of salt snow-melting agent solution, and the smallest is in the $20 \%$ solution.

(4) The frost-salt has important influence on the compressive and flexural strength of concrete. With the increasing of frost-salt cycles, the concrete strength will gradually decrease, while the relative dynamic elastic modulus reduces quickly.

\section{CONFLICT OF INTEREST}

This article content has no conflict of interest.

\section{ACKNOWLEDGEMENTS}

The authors are thankful to the Postdoctoral fund project of Jiangsu province China (1301057B), the 55th batche Postdoctoral Science Foundation of China (2014M551588), the Construction system project of Jiangsu province China (2013ZD12), and the science and technology projects of Ministry of Housing and UrbanRural Development of the People's Republic of China (2013-R1-18) for its financial support for this project.

\section{REFERENCES}

[1] H. K. Steven, K. Beatrix, and C. P. William, Design and Control of Concrete Mixtures, Portland Cement Association, 2003.

[2] Z. Li, and H. Ba, "Study on the freeze-deicing salt resistance of the pavement concrete," Journal of Sichuan University (Engineering Science Edition), (in chinese) vol. 40, no.5, pp. 8083, 2008.

[3] C. Sun, and D. Niu, "Experiment 1 study on frost-salt resistance of concrete," Bulletin of the Chinese Ceramic Society, (in chinese), vol. 29, no.4, pp. 762-767, 2010.

[4] R. Sahin, and M. A. Tasdemir, R. Güla, and C. Çelik, "Determination of the optimum conditions for de-icing salt scaling resistance of concrete by visual examination and surface scaling," Construction and Building Materials, pp. 1-8, 2009.
[5] S. Pack, M. Jung, and H. Song, "Prediction of time dependent chloride transport in concrete structures exposed to a marine environment," Cement and Concrete Research, vol. 40, no.2, pp. 302-312, 2010.

[6] H.W. Song, H.B. Shim, A. Petcherdchoo, and S.K. Park, "Service life prediction of repaired concrete structures under chloride environment using finite difference method," Cement and Concrete Composites, vol. 31, no. 2, pp. 120-127, 2008.

[7] T. Cheewaket, C. Jaturapitakkul, and W. Chalee, "Long term performance of chloride binding capacity in fly ash concrete in a marine environment," Construction and Building Materials, vol. 24, pp. 1352-1357, 2010.

[8] H. LI "Corrosion and protective Measure after a large quantity of spreading salt," Journal of Shandong Jianzhu University, (in chinese) vol. 24, pp. 184-188, 2009.

[9] Z. Hui, P. Yonqiang, Z. Jian, and Z. Lei, "Influence factors of frost-salt resistance of cement concrete," Journal of Chongqing Jiaotong University(Natural Science), (in chinese) vol. 4, no. 32, pp.597-600, 2013

[10] Z. Wu, D. Chen, P. Gao, F. Geng, X. Huang, and M. Huang, "Effect of chloride salt and freezing-thawing on deicer-scaling resistance of concrete," Bulletin of the Chinese Ceramic Society, (in chinese) vol. 30, no. 6, pp. 1244-1248, 2011.

[11] F. Xiao, "Danger to the bridge and prevention of snow-melting agent," Northern Communications, (in chinese) no. 3, pp. 82-85, 2013.

[12] Q. Yang, "Mechanisms of deicer-frost scaling of concrete (I): capillary-uptake degree of saturation and ice-formation pressure," Journal of Building Materials, (in chinese) vol. 10, no. 5, pp. 522-527, 2007.

[13] K.Y. Ann, J.H. Ahn, and J.S. Ryou, "The importance of chloride content at the concrete surface in assessing the time to corrosion of steel in concrete structures," Construction and Building Materials, vol. 23, no. 1, pp. 239-245, 2009.

[14] M. K. Moradllo, M. Shekarchi, and M. Hoseini, "Timedependent performance of concrete surface coatings in tidal zone of marine environment," Construction and Building Materials, no. 30, pp. 198-205, 2012.

[15] C. Andrade, M. Prieto, P. Tanner, F. Tavares, and R. d'Andrea. "Testing and modelling chloride penetration into concrete," Construction and Building Materials, vol. 39, pp. 9-185, 2013. 